\title{
7. PRESSURE CORE BARREL: APPLICATION TO THE STUDY OF GAS HYDRATES, DEEP SEA DRILLING PROJECT SITE 533, LEG 76 ${ }^{1}$
}

\author{
Keith A. Kvenvolden, Pacific-Arctic Branch of Marine Geology, U.S. Geological Survey, Menlo Park, California \\ Leo A. Barnard, Department of Oceanography, Texas A\&M University, College Station, Texas \\ and \\ Donald H. Cameron, Deep Sea Drilling Project, Scripps Institute of Oceanography, La Jolla, California
}

\begin{abstract}
A pressure core barrel (PCB), developed by the Deep Sea Drilling Project, was used successfully to recover, at in situ pressure, sediments of the Blake Outer Ridge, offshore the southeastern United States. The PCB is a unique, wire-line tool, $10.4 \mathrm{~m}$ long, capable of recovering $5.8 \mathrm{~m}$ of core $(5.8 \mathrm{~cm}$ in diameter), maintained at or below in situ pressures of 34.4 million Pascals (MPa), and $1.8 \mathrm{~m}$ of unpressurized core $(5.8 \mathrm{~cm}$ in diameter). All excess internal pressure above the operating pressure of $34.4 \mathrm{MPa}$ is automatically vented off as the barrel is retrieved.

The PCB was deployed five times at DSDP Site 533 where geophysical evidence suggests the presence of gas hydrates in the upper $600 \mathrm{~m}$ of sediment. Three cores were obtained holding average in situ pressures of $30 \mathrm{MPa}$. Two other cores did not maintain in situ pressures. Three of the five cores were intermittently degassed at varying intervals of time, and portions of the vented gas were collected for analysis. Pressure decline followed paths indicative of gas hydrates and/or dissolved gas. The released gas was dominantly methane (usually greater than $90 \%$ ), along with higher molecular-weight hydrocarbon gases and carbon dioxide. During degassing the ratio of methane to ethane did not vary significantly. On the other hand, concentrations of higher molecular-weight hydrocarbon gases increased, as did carbon dioxide concentrations. The results from the PCB experiments provide tentative but equivocal evidence for the presence of gas hydrates at Site 533. The amount of gas hydrate indicated is small. Nevertheless, this work represents the first successful study of marine gas hydrates utilizing the PCB.
\end{abstract}

\section{INTRODUCTION}

The Deep Sea Drilling Project (DSDP) has been a leader in the development of new, sophisticated technology for deep ocean drilling (Larson et al., 1980). Among the Project's important technological advances is a unique, wire-line, retrievable pressure core barrel (PCB) capable of recovering sediment cores at original formation pressures. In such cores, pressure-related changes that accompany conventional core recovery are inhibited or prevented; the core is maintained essentially as it was at depth.

The PCB is especially useful for the study of gas hydrates in oceanic sediments. Gas hydrates are naturally occurring, crystalline solids composed of a three-dimensional framework of water molecules that is initiated and stabilized by included molecules of gas, mainly methane in marine sediments. Appropriate conditions of high pressures and moderate temperatures are found in deep oceanic sediments where natural gas (methane), in excess of the amount soluble in water, will interact with water to form gas hydrates. Kvenvolden and McMenamin (1980) and Kvenvolden and Barnard (in press) have reviewed the known and inferred occurrences of gas hydrates in oceanic sediments and have shown that gas hydrates are likely to be common in continental margin sediments throughout the world. Gas hydrates decompose upon decrease of pressure and increase in temperature. The

\footnotetext{
${ }^{1}$ Sheridan, R. E., Gradstein, F. M., et al., Init. Repts. DSDP, 76: Washington (U'.S. Govt. Printing Office).
}

PCB provides an appropriate device to recover at nearly in situ conditions sediment containing gas hydrate. Within the PCB a recovered gas hydrate can be decomposed under controlled conditions and samples of gas obtained for analysis. The observed pressure changes and compositional analyses can be used to verify that gas hydrates have been cored and to determine the sources of the gas.

\section{HISTORY OF DEVELOPMENT OF THE PCB}

Although the need for a PCB was recognized early on at DSDP, the development of a successful coring system took several years. An early version of the PCB was deployed at Site 185 on Leg 19 in the southeastern Bering Sea. Unfortunately this PCB jammed, shearing the pin in the sand-line recovery mechanism, which made it necessary to abandon the hole (Creager, Scholl, et al., 1973). A modified PCB (Mod. I) was tested eleven times during Leg 42B in the Black Sea with varying degrees of success (Ross, Neprochnov, and Supko, 1978): at Site 379 this PCB was used six times to recover sediment, but no pressures are given (Ross, Neprochnov, et al., 1978a). Four tests with this PCB were made at Site 380 ; in one of these tests gas compositions were measured, but this tool failed on subsequent tests (Ross, Neprochnov, et al., 1978b). The PCB was given its eleventh test at Site 381 , but no results are reported (Ross, Neprochnov, et al., 1978c). As a result of the PCB testing on Leg 42B several modifications were recommended, and two attempts were made to test the PCB at Site 388 of Leg 44 on the western Atlantic continental margin, (Benson, Sheridan, et al., 1978). Both tests were unsuccessful due 
to the failure of the ball assembly to close and maintain pressure.

On the basis of the preceding tests the PCB was extensively modified, and a second version (Mod. II) was tested on Legs 62, 64, 66, 72 and 74 in both the Pacific and Atlantic Oceans. Only results from Leg 62 are currently available (Thiede et al., 1981). On this leg the PCB was deployed five times at two different sites. On three of the tests the PCB maintained some pressure. Two cores were recovered, but the occurrence of chert limited the degree of success of PCB coring on this leg. During the series of tests on Legs 62, 64, 66, 72, and 74 a dependable ball-valve seal and an upper exhaust-vent seal evolved.

One problem that remained to be solved was the sporadic, premature tripping of the ball closure, vent, and release mechanisms. Ultimately the problem was traced to shear pins, which should have sheared during increasing pull on the wire line, thereby triggering the ball closure, vent, and release mechanisms in three separate steps. The shear pins, however, became weakened during the trip down the pipe and, upon impact with the bit, sheared prematurely, causing the release of the tool before closure of the ball valve.

The last version (Mod. III) of the PCB (Fig. 1) incorporates, instead of shear pins, a system combining a collet, ball locks, and a stack of disk springs. The pressure relief valve is located outside the pressure chamber. Two alternate sampling assemblies are available for use. The primary assembly incorporates a floating piston accumulator $\left(500 \mathrm{~cm}^{3}\right.$ capacity) in-line between the pressure chamber-containing the pressurized core-and the pressure relief valve. The other sampling assembly uses a sediment trap and a 20 -micron filter instead of an accumulator.

Now the Mod. III PCB (Fig. 1) consists of a high-pressure, wire-line core barrel terminating in a ball-valve assembly with a $5.8-\mathrm{cm}$-diameter orifice at the lower end and a sampling mechanism, exhaust vent, and pressure relief valve at the upper end. The PCB is dropped down the drill string to latch in at the drill bit. After the core is cut by rotary coring, a retrieving tool is lowered down the pipe by wire line to latch onto the PCB. The force of the wire-line pull against the latched-in PCB activates a series of mechanisms that shift close the ball valve and the exhaust vent and finally unlatch the tool. As the PCB is retrieved, the pressure relief valve maintains internal pressure at no more than 34.4 million Pascals (MPa) (5000 psi) by venting nitrogen from the precharged floating piston accumulator, if the primary assembly is used, or by releasing excess pressure through the sediment trap and filter if the alternate assembly is in place. When the floating piston accumulator is used (Fig. 1) and is initially charged with nitrogen to about $27.5 \mathrm{MPa}$ (4000 psi), a barrel pressure exceeding $27.5 \mathrm{MPa}$ will cause the piston to compress the nitrogen. When the pressure in the sampling chamber of the PCB exceeds 34.4 $\mathrm{MPa}$, the pressure relief valve opens and vents only nitrogen, thereby saving the gas in the sediment sample and protecting the pressure relief valve from possible clogging with sediment.
When the PCB reaches the deck, the pressure and temperature of the core can be monitored, and pressurized gas and fluids can be withdrawn under controlled conditions. The unique, wire-line retrieval system allows several pressurized cores to be collected while coring progressively in the same drill hole. This procedure contrasts with more conventional pressure-coring systems used by the petroleum industry that require a complete round trip with the drill string for recovery of each core.

\section{SPECIFICATIONS FOR MOD. III PCB}

A detailed diagram of the Mod. III PCB with the floating piston accumulator (Fig. 1) illustrates both the latched configuration used during coring and the unlatched configuration used during core retrieval. Operating specifications and general information on this $\mathrm{PCB}$ are as follows:

Operating Pressure. A pressure relief valve maintains the system at or below $34.4 \mathrm{MPa}(5000 \mathrm{psi})$ independent of the hydrostatic pressure encountered.

Safety. Internal-burst (yield) strength of the system is $137 \mathrm{MPa}(20,000 \mathrm{psi})$. The factor of safety is $4: 1$ at the $34.4 \mathrm{MPa}$ operating pressure. A burst disk will rupture at 48 to $55 \mathrm{MPa}(7000-8000 \mathrm{psi})$ in case the pressure relief valve fails.

Core Diameter. Nominal diameter is 5.78 instead of the $6.43-\mathrm{cm}$ diameter of the standard DSDP rotary coring system. A special core bit is used at a hole in the pressure coring program. The standard, unpressurized, wire-line coring utilizes the same bit at the hole and recovers cores of the smaller diameter. The volume of sediment cored with the smaller bit is about $19 \%$ less than the volume of sediment cored with the standard bit. A reentry scanning sonar tool has been designed to protrude through the smaller bit. Thus pressurized core recovery, unpressurized rotary core recovery, and reentry with scanning sonar tool are all compatible. Pressurized core recovery is not compatible, however, with hydraulic piston coring.

Core Length. Approximately $1.8 \mathrm{~m}$ of unpressurized core and approximately $5.8 \mathrm{~m}$ of pressurized core can be recovered.

Core Liner. The PCB utilizes the same butyrate core liner as the standard DSDP coring system. The $1.8 \mathrm{~m}$ of unpressurized core is not recovered in a liner.

Barrel Length. The total length of the PCB is the same as the standard DSDP wire-line coring assembly of $10.4 \mathrm{~m}$ (34 ft., $0.10 \mathrm{in}$.).

Sampling. A sampling port ( 0.25 NPT, National Pipe Thread) is provided in the sampling assembly near the upper end of the PCB to permit sampling of gases and fluids after the tool has reached the deck. Pressure and temperature can be measured immediately without opening the pressurized core barrel. Pressure is monitored through a pressure transducer, and temperature is monitored through a blind port filled with a heat sink compound into which a temperature probe is inserted.

Water Depth. The PCB can operate safely in a $6100-\mathrm{m}$ $(20,000$-ft.) water depth. All excess internal pressure above operating pressure (34.4 $\mathrm{MPa})$ is automatically 
Stage 1

1. Ball valve is open

2. Ball valve assembly is latched

3. Drilling and coring ahead
Stage 2

1. Ball valve assembly is unlatched
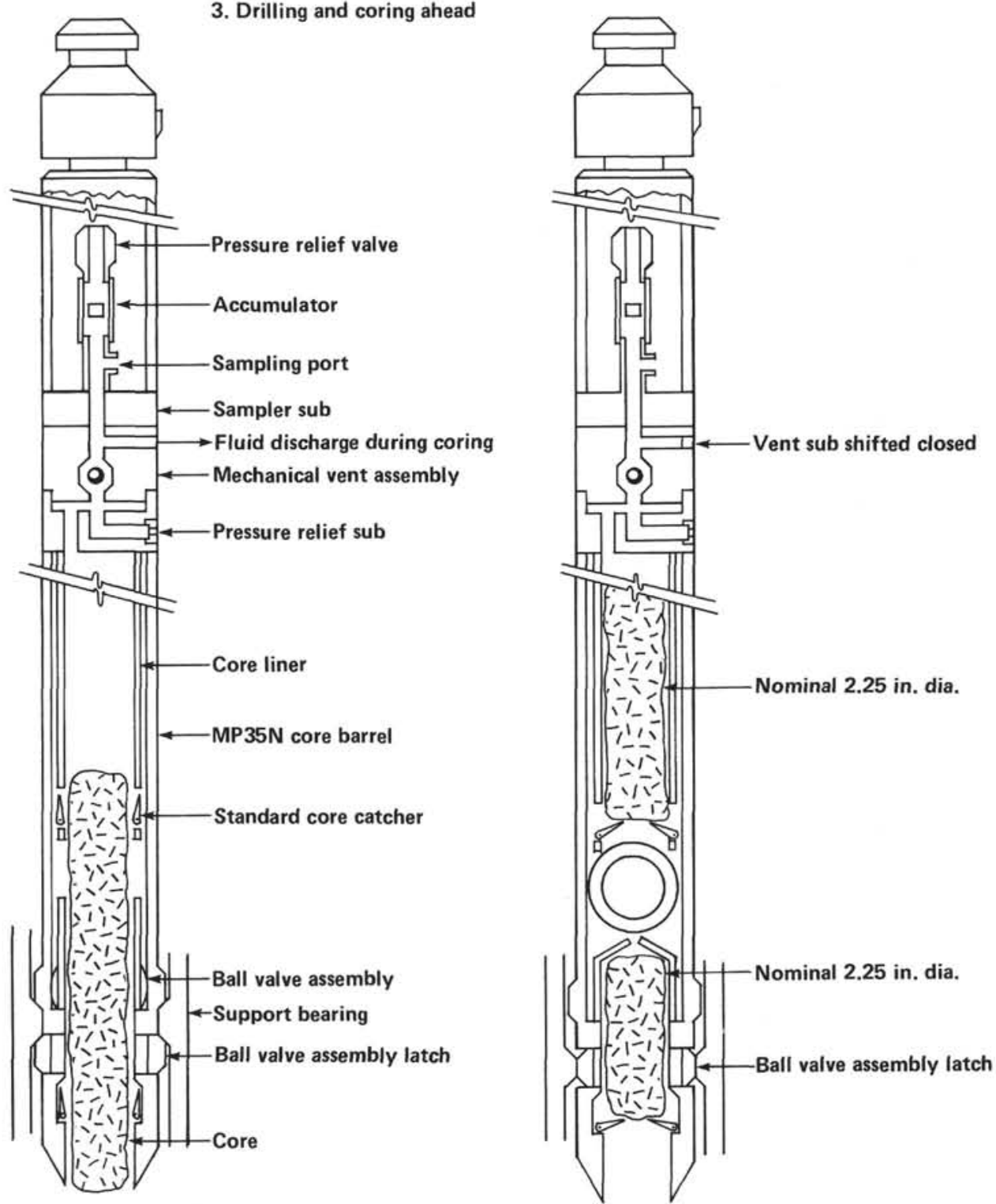

Figure 1. Mod. III pressure core barrel. (Stage 1 shows the configuration of the PCB during drilling and coring with the ball valve open and the ball valve assembly latched to the drill pipe. Stage 2 shows the configuration of the PCB during core recovery. The ball valve and vent sub have closed, sealing the pressurized core in the pressure chamber. The unpressurized core is held in place at the lower end of the tool by a core catcher. The PCB has been unlatched from the drill pipe.)

vented off as the barrel is retrieved. Thus at water depths greater than $3050 \mathrm{~m}(10,000 \mathrm{ft}$.) excess pressure is vented.

Operating Time. Operating time for the PCB is comparable to that of the standard DSDP wire-line rotary coring system. However, the ball-valve assembly must be totally redressed after each run, and this operation requires 2 to $5 \mathrm{hr}$. Thus the frequency with which the PCB can be deployed is limited by the number of available ball-valve assemblies. Handling time on deck is a function of the required scientific program.
Theory of Operation. Unlike the standard core barrel, the PCB latches in under the support bearing located just above the rotary drill bit. After the core is drilled, a wire-line is sent down to retrieve the tool. A pressure seal is effected by rotating the ball valve at the lower end and shifting closed the exhaust vent in the upper end of the core barrel. Each of these mechanisms is activated by a wire-line pull of somewhat less force than is required to unlatch the tool from the support bearing. The resistance of the latch can be adjusted by altering the 
configuration of the stack of disk springs. The force needed to unlatch the PCB ranges from 2000 to $6000 \mathrm{lb}$. over the wire-line weight.

\section{PCB DEPLOYMENT AT SITE 533}

The Mod. III PCB was deployed five times at Site 533 in $3184 \mathrm{~m}$ of water at sediment depths between 152 and $399 \mathrm{~m}$ (Table 1). Three cores (PCB-1, PCB-3, and PCB5) were recovered at approximately in situ pressures between 27.5 and $32.3 \mathrm{MPa}$. PCB-4 had only $10.3 \mathrm{MPa}$ pressure due possibly to a temporarily jammed pressure relief valve. PCB-2 had no pressure because of a missing plug. This PCB contained no sediment core in the upper chamber (Fig. 1), and was the only PCB to recover unpressurized core in the lower chamber (Fig. 1). The pressurized sediment cores were intermittently degassed at varying intervals of time, and portions of the gas were collected for analysis by venting the gas through a transfer manifold and high-pressure regulator into steel sampling cylinders (Fig. 2).

\section{PCB-1}

At Site 533 the first $167.5 \mathrm{~m}$ of sediment (Hole 533) was cored with the hydraulic piston corer (HPC), another DSDP technological innovation (Larson et al., 1980). The first PCB was not deployed at this point because the PCB and HPC do not have compatible bottom-hole assemblies. Instead, the drill pipe was pulled. A standard rotary coring assembly, through which PCB coring could be accomplished, was installed, and the drill pipe was lowered to commence Hole 533A. At $152.0 \mathrm{~m}$, PCB-1 was deployed to recover Core 3 from this hole.

PCB-1 latched in properly, but circulation was lost as soon as coring commenced. Normally during the coring

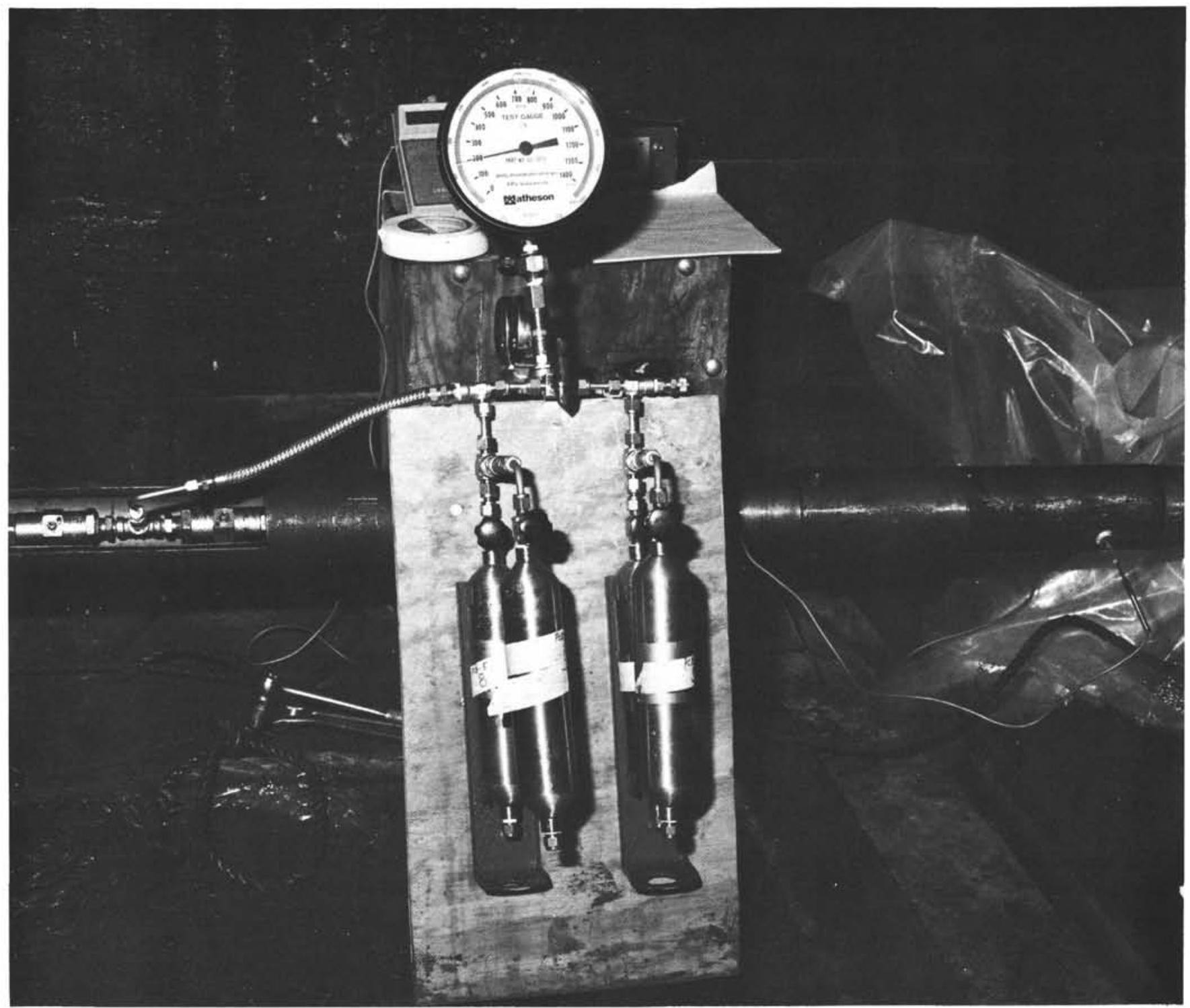

Figure 2. Gas transfer manifold showing pressure gauge and valves for controlling gas flow into evacuated cylinders. (A pressure transducer measures the internal pressure of the PCB and a digital thermometer measures the temperature of the PCB through an unused port filled with a heat sink compound that permits insertion of a temperature probe.) 
operation water is circulated at a low flow rate around the core barrel to lubricate the bit and remove cuttings. Without water circulation a $2.5-\mathrm{m}$ dry core was cut. To unlatch the barrel $8500-\mathrm{lb}$. pull was required. This pull was $4500 \mathrm{lb}$. over the line weight of $4000 \mathrm{lb}$. (Table 1). Previous tests on the "C" spring-pack configuration, defined in Table 1, had indicated that the PCB should release with a pull of $3000 \mathrm{lb}$. The loss of circulation and the high unlatching loads were attributed to rust jamming the tool in the drill pipe. Although circulation was restored by cutting flutes in the land shoulder of the coring assembly, the unlatching loads continued to be high on subsequent runs even though a weaker spring-pack configuration "D"' was used (Table 1).

After recovery on deck, the pressure within PCB-1 was measured at $27.5 \mathrm{MPa}$. The tool was immersed in a bath at $25.7^{\circ} \mathrm{C}$ and was degassed over a period of $3 \mathrm{hr}$. (Fig. 3). During degassing soupy mud clogged the filters of the transfer manifold (Fig. 2). No gas samples were collected for analysis, but the degassing was monitored (Fig. 3) after the filters were bypassed. The pressure was reduced to atmospheric three times. After the first two pressure reductions, the pressure recovered to about $2 \mathrm{MPa}$ after the valve was closed.

Although $2.5 \mathrm{~m}$ of sediment were cored (152.0-154.5 $\mathrm{m}), 6.4 \mathrm{~m}$ of material were recovered. This material consisted of a slurry of drilling fluids, cuttings, and a very disrupted sediment core. Much of the material had a frothy appearance, suggesting rapid degassing and the possible presence of gas hydrates.

\section{PCB-2}

PCB-2 was deployed to core the interval from 247.0 to $254.8 \mathrm{~m}$ (Hole 533A, Core 14). The decision to use the PCB at this interval was based on the observation of gas hydrate-containing sediment in Core 13, described by Kvenvolden and Barnard (this volume). PCB-2 operated well mechanically except for the high load required for unlatching (Table 1). Although this PCB functioned properly, it failed to maintain in situ pressure because of a missing plug and a faulty core liner. A plug had been inadvertently left out of the sampling assembly, and the core liner returned totally shattered. This liner had been used previously downhole and may have become brittle. Also the liner had been spliced, although the splice was not used inside the pressure chamber of the barrel. PCB2 was the only PCB to recover core $(1.6 \mathrm{~m})$ in the unpressurized section of the barrel below the ball valve (Fig. 1). The recurring failure to recover unpressurized core in this section of the barrel may have been caused

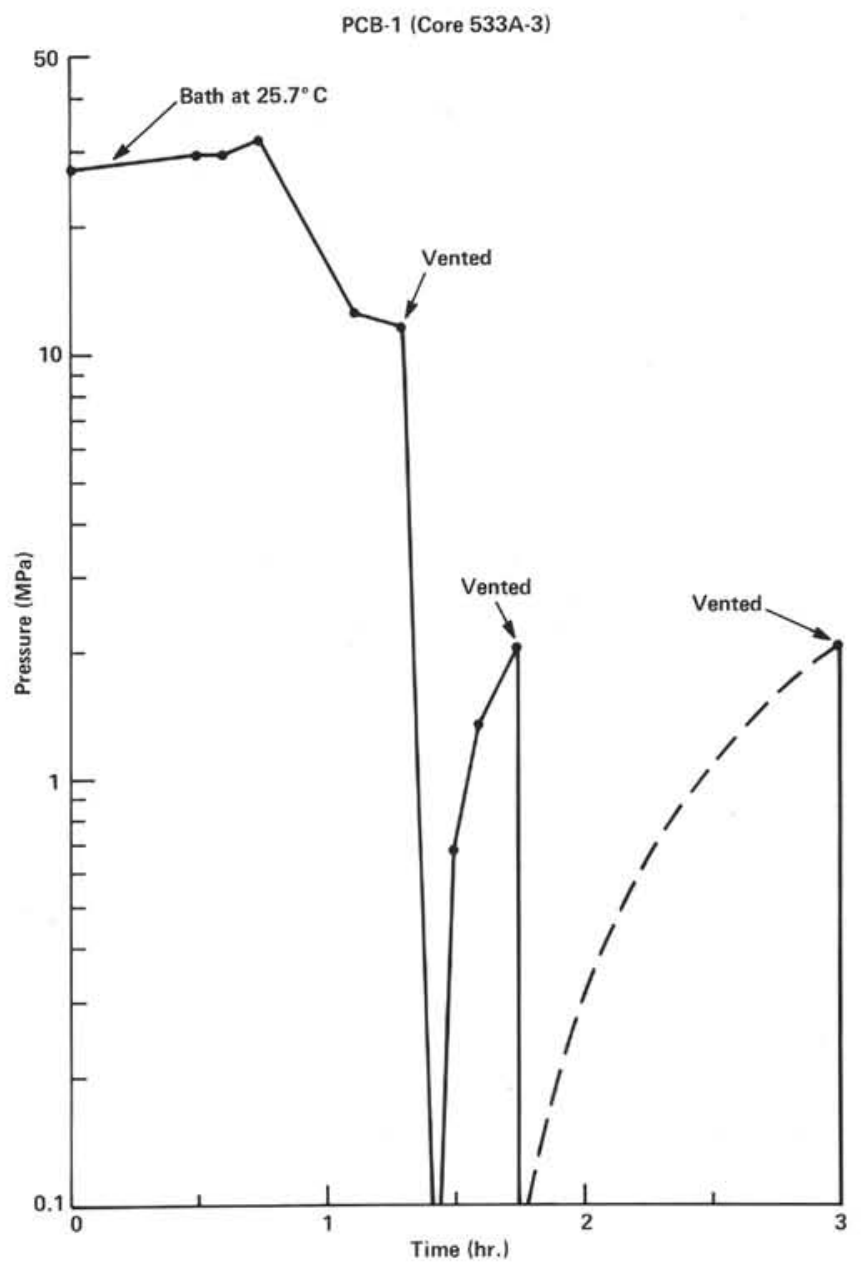

Figure 3. Pressure changes that took place during degassing of PCB-1. (Pressure scale is logarithmic in MPa [million Pascals] and time is in hours. Points where pressures were recorded are indicated with dots. The $\mathrm{PCB}$ was placed in a bath at $25.7^{\circ} \mathrm{C}$ after it was recovered on deck.)

by the single lower core catcher allowing the fine-grained hemipelagic sediment to wash through. The failure may also be correlated with the high loads necessary to unlatch the PCB. Examination of the recovered $1.6 \mathrm{~m}$ of unpressurized core showed no frothing or other evidence attributable to the presence of gas hydrates.

\section{PCB-3}

Sediment in cores recovered by conventional rotary coring beneath the interval cored by PCB-2 (Core 14) was semiconsolidated, with disruption and gaps due to

Table 1. Pressure core barrel sampling in Hole 533A.

\begin{tabular}{|c|c|c|c|c|c|c|c|c|}
\hline \multirow[b]{2}{*}{$\begin{array}{l}\text { PCB } \\
\text { no. }\end{array}$} & \multirow[b]{2}{*}{$\begin{array}{l}\text { Core } \\
\text { no. }\end{array}$} & \multirow{2}{*}{$\begin{array}{l}\text { Sediment depth } \\
\text { interval cored } \\
(\mathrm{m})\end{array}$} & \multicolumn{2}{|c|}{ Recovery } & \multirow[b]{2}{*}{$\begin{array}{l}\text { Pressure } \\
(\mathrm{MPa})\end{array}$} & \multirow[b]{2}{*}{$\begin{array}{l}\text { Sampling } \\
\text { assemblya }\end{array}$} & \multirow[b]{2}{*}{$\begin{array}{l}\text { Spring } \\
\text { packb }\end{array}$} & \multirow{2}{*}{$\begin{array}{l}\text { Wire-line load } \\
\text { to unlatch in lb. } \\
\text { (overpull, lb.) }\end{array}$} \\
\hline & & & $\begin{array}{l}\text { Pressurized } \\
\text { (m) }\end{array}$ & $\begin{array}{l}\text { Unpressurized } \\
\text { (m) }\end{array}$ & & & & \\
\hline 1 & 3 & $152.0-154.5$ & 6.4 & 0 & 27.5 & A & C & $8500(4500)$ \\
\hline 2 & 14 & $247.0-254.8$ & 0 & 1.6 & 0 & A & C & $9000(5000)$ \\
\hline 3 & 23 & $332.5-340.3$ & 6.1 & 0 & 32.3 & A & D & $9500(5500)$ \\
\hline 4 & 26 & $361.0-368.8$ & 6.1 & 0 & 10.3 & B & D & $9000(5000)$ \\
\hline 5 & 29 & $392.2-399.0$ & 6.2 & 0 & 30.2 & A & D & $10,000(6000)$ \\
\hline
\end{tabular}

a $\mathrm{A}=$ Primary assembly with floating piston accumulator; $\mathrm{B}=$ alternate assembly with traps and filter.

${ }^{b} \mathrm{C}=$ Series parallel stack of 44 spring washers; $\mathrm{D}=$ series parallel stack of 42 spring washers. 
gas but no frothing or other evidence indicating gas hydrates. In spite of the lack of direct evidence for gas hydrates a plan was evolved to deploy the PCB three times at regular intervals until the target total depth of $399 \mathrm{~m}$ was reached. PCB-3 cored the interval 332.5 to $340.3 \mathrm{~m}$, recovering $6.1 \mathrm{~m}$ of Core 23 at a pressure of $32.3 \mathrm{MPa}$ (Table 1). This PCB was immediately immersed in an ice bath at $0^{\circ} \mathrm{C}$ and degassed through the transfer manifold for about $3 \mathrm{hr}$.; gas samples were collected in 15 evacuated cylinders (Fig. 4). Filling the first 4 cylinders reduced the pressure to about $2 \mathrm{MPa}$. After the valve was closed the pressure built up to $3.3 \mathrm{MPa}$, and 4 more cylinders were filled, reducing the pressure to $2.3 \mathrm{MPa}$. Again the pressure rose slightly to $2.5 \mathrm{MPa}$, and 4 more cylinders were filled with gas, reducing the pressure to 1.7 $\mathrm{MPa}$. When the valve was again closed the pressure increased to $1.9 \mathrm{MPa}$, and after a single gas sample was taken, the system was vented to atmospheric pressure. The tool remained in the ice bath for $2 \mathrm{hr}$., at which time it was moved to a bath at $27.7^{\circ} \mathrm{C}$. After a pressure increase of $0.2 \mathrm{MPa}$, two more cylinders were filled. Samples of gas from 6 of the 15 cylinders were analyzed by gas chromatography aboard ship (Table 2). When the sediment core was examined no direct evidence for gas hydrates was observed, although the sediment showed some disruptions and gaps due to gas.

\section{PCB-4}

The interval from 361.0 to $368.8 \mathrm{~m}$ was cored by PCB4 , and $6.1 \mathrm{~m}$ of Core 26 were recovered at $10.3 \mathrm{MPa}$ (Table 1). PCB-4 was the only PCB that did not use the floating piston accumulator, but rather used the sediment trap and filter in the pressure relief valve of the sampling assembly. This pressure relief valve may have jammed because of muddy water passing through the filter, thus causing a partial loss of pressure in the sample chamber. PCB-4 was degassed into one cylinder, immediately vented to atmospheric pressure, opened, and inspected for the presence of gas hydrates. None was found. Collected gases were analyzed by gas chromatography aboard ship (Table 2).

\section{PCB-5}

The last core to be taken at Hole 533A was with PCB-5. Coring the interval 392.2 to $399.0 \mathrm{~m}$ produced $6.2 \mathrm{~m}$ of Core 29 at $30.2 \mathrm{MPa}$ (Table 1). As in the case of PCB-3, PCB-5 was immersed in an ice bath and de-

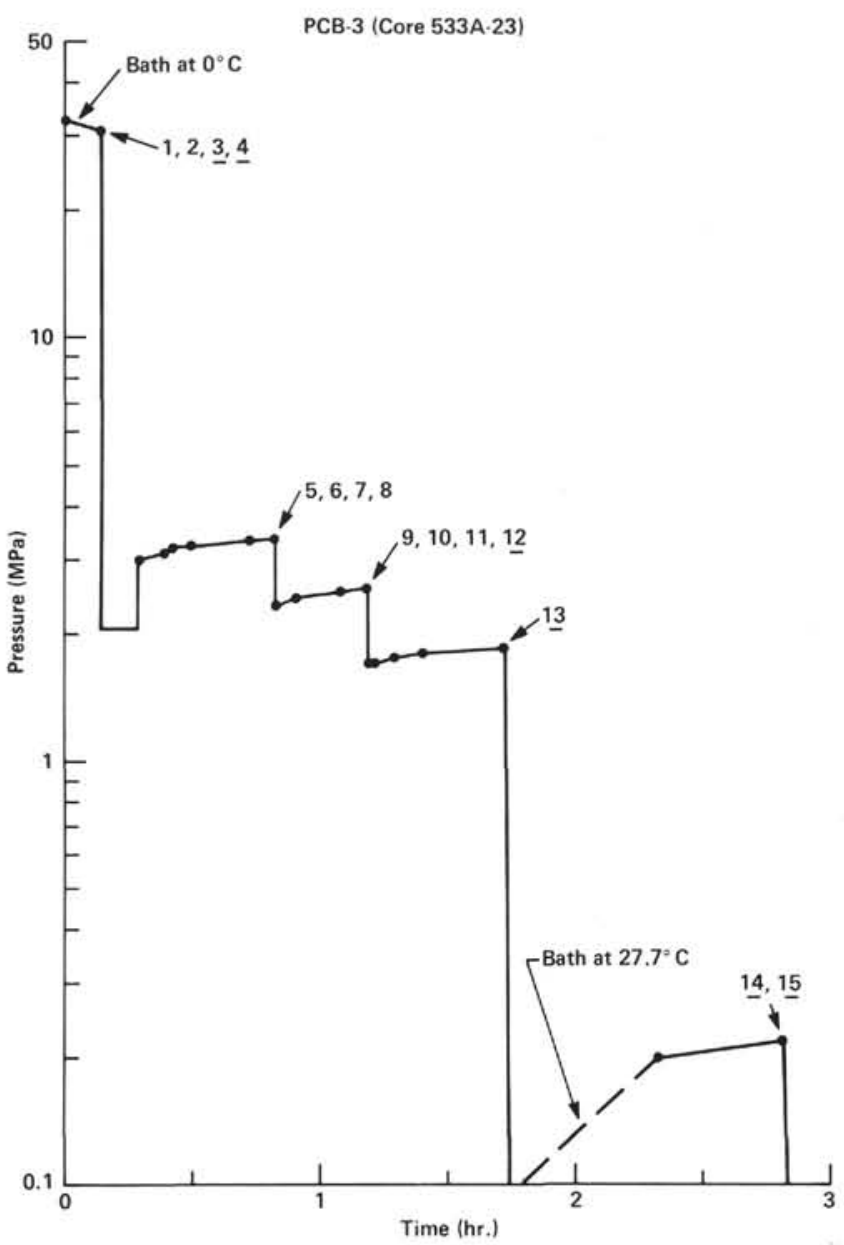

Figure 4. Pressure changes that took place during degassing of PCB-3. (Pressure and time scales are the same as in Fig. 3. Pressure measurements are indicated with dots. Evacuated cylinders [1-15] were filled with gas where indicated; underlined cylinder numbers indicate the cylinders from which gas was recovered for shipboard analyses. The PCB was first placed in a $0^{\circ}$ bath and later switched to a bath at $27.7^{\circ} \mathrm{C}$.)

gassed for $1.5 \mathrm{hr}$., at which time the tool was moved to a seawater bath at $26.7^{\circ} \mathrm{C}$. The temperature of this bath increased slowly over the next $2 \mathrm{hr}$. to $28.8^{\circ} \mathrm{C}$ (Fig. 5). A total of 16 evacuated cylinders were filled during the course of the degassing. The first 4 cylinders were filled and the pressure reduced to atmospheric. After the valve was closed, pressure increased to $1.4 \mathrm{MPa}$. When the next

Table 2. Composition of gases recovered from pressure core barrels at Site 533.

\begin{tabular}{ccccccccccccc}
\hline $\begin{array}{c}\mathrm{PCB} \\
\text { no. }\end{array}$ & $\begin{array}{c}\text { Core } \\
\text { no. }\end{array}$ & $\begin{array}{c}\text { Cylinder } \\
\text { no. }\end{array}$ & $\begin{array}{c}\text { Interval } \\
(\mathrm{m})\end{array}$ & $\begin{array}{c}\mathrm{C}_{1} \\
(\%)\end{array}$ & $\begin{array}{c}\mathrm{C}_{2} \\
(\mathrm{ppm})\end{array}$ & $\begin{array}{c}\mathrm{C}_{3} \\
(\mathrm{ppm})\end{array}$ & $\begin{array}{c}\mathrm{i}-\mathrm{C}_{4} \\
(\mathrm{ppm})\end{array}$ & $\begin{array}{c}n-\mathrm{C}_{4} \\
(\mathrm{ppm})\end{array}$ & $\begin{array}{c}\mathrm{i}-\mathrm{C}_{5} \\
(\mathrm{ppm})\end{array}$ & $\begin{array}{c}n-\mathrm{C}_{5} \\
(\mathrm{ppm})\end{array}$ & $\begin{array}{c}\mathrm{CO}_{2} \\
(\%)\end{array}$ & $\mathrm{C}_{1} / \mathrm{C}_{2}$ \\
\hline 3 & 23 & 3.4 & $332.5-340.3$ & 76 & 102 & 4.2 & 1.8 & 0.5 & 0.8 & 0.6 & 1.5 & 7500 \\
3 & 23 & 12 & $332.5-340.3$ & 96 & 171 & 5.8 & 1.9 & 0.7 & 1.2 & 0.5 & 0.9 & 5600 \\
3 & 23 & 13 & $332.5-340.3$ & 95 & 143 & 5.7 & 1.5 & 0.5 & 0.8 & 1.1 & 0.4 & 6600 \\
3 & 23 & 14 & $332.5-340.3$ & 90 & 179 & 5.7 & 3.0 & 0.7 & 1.6 & 0.3 & 5.0 & 5000 \\
3 & 23 & 15 & $332.5-340.3$ & 90 & 181 & 8.5 & 4.5 & 0.0 & 0.5 & 0.2 & 4.7 & 5000 \\
4 & 26 & 6 & $361.0-368.8$ & 7.0 & 13 & 0.7 & 0.2 & 0.2 & 0.2 & 0.1 & 0.04 & 5400 \\
5 & 29 & 3 & $392.2-399.0$ & 94 & 234 & 6.1 & 1.5 & 0.6 & 0.3 & 0.2 & 0.2 & 4000 \\
5 & 29 & 9 & $392.2-399.0$ & 97 & 242 & 8.0 & 1.6 & 0.7 & 0.5 & 0.3 & 0.5 & 4000 \\
5 & 29 & FR & $392.2-399.0$ & 96 & 237 & 11.9 & 2.5 & 1.5 & 1.3 & 0.6 & 1.8 & 4100 \\
5 & 29 & LB-1 & $392.2-399.0$ & 97 & 237 & 12.5 & 4.0 & 1.6 & 1.7 & 0.8 & 0.3 & 4100 \\
5 & 29 & LB-3 & $392.2-399.0$ & 94 & 230 & 15.8 & 4.5 & 2.0 & 2.2 & 1.5 & 1.9 & 4100 \\
5 & 29 & L.B-6 & $392.2-399.0$ & 94 & 223 & 18.5 & 5.5 & 2.4 & 2.7 & 1.3 & 2.4 & 4200 \\
\hline
\end{tabular}

Note: Letter designation of cylinders indicates the type of container used. FR is a container that previously held freon. LB indicates containers that previously were gas lecture bottles. 


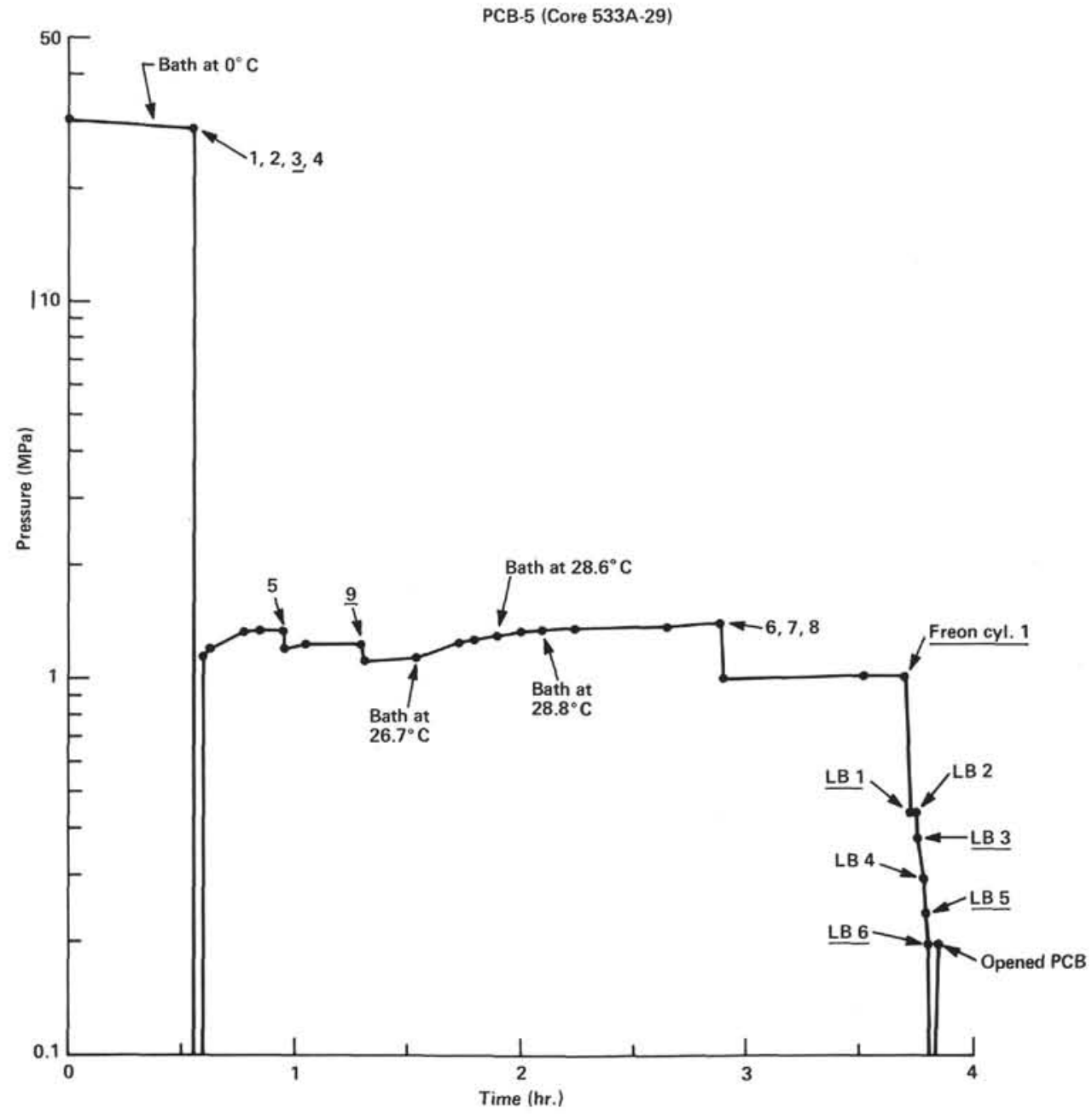

Figure 5. Pressure changes that took place during degassing of PCB-5. (Caption for Fig. 4 applies, except that the second bath was at $26.7^{\circ} \mathrm{C}$ and changed temperatures to $28.8^{\circ} \mathrm{C}$. The LB designation indicates sample cylinders that previously were gas lecture bottles.)

two cylinders were filled, the pressure decreased slightly but rose again after the valve was closed. Pressure rose from 1.2 to $1.4 \mathrm{MPa}$ when the tool was moved from the ice bath and immersed in the seawater bath for $2 \mathrm{hr}$. After 3 cylinders were filled, pressure dropped from 1.4 to about $1.0 \mathrm{MPa}$, where the pressure remained constant until a large evacuated container, previously containing freon, was filled to about $0.035 \mathrm{MPa}$. Six cylinders were then filled as the pressure decreased from 0.4 to 0.2 $\mathrm{MPa}$. After the tool was vented to atmospheric pressure and closed, the pressure returned to $0.2 \mathrm{MPa}$. Of the 16 cylinders filled with gas, the contents of 6 of these were analyzed by gas chromatography aboard ship (Table 2). Examination of the recovered sediment core showed evidence of gas but no unequivocal evidence of gas hydrates.

\section{INTERPRETATION OF PRESSURE CURVES}

Hunt (1979, pp. 160-161) discusses a means of identifying gas hydrates in the subsurface by use of a pressure core barrel. The internal pressure is measured as gas is vented from the barrel. If only free gas is present, the pressure will decline approximately as shown in Figure 6.

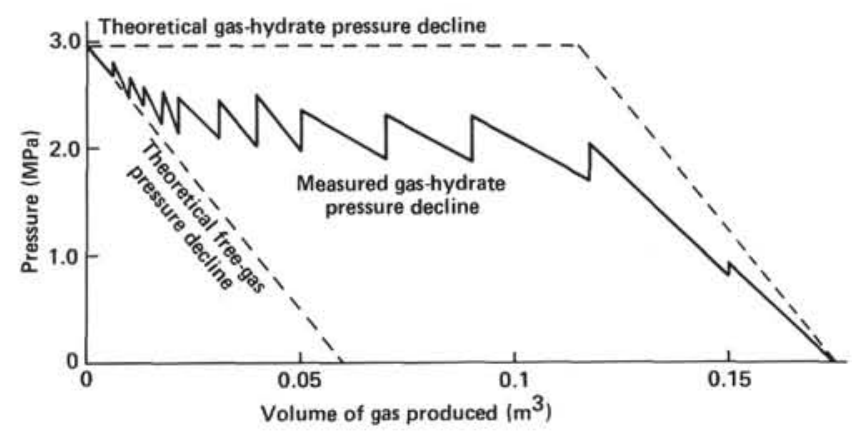

Figure 6. Graph showing expected pressure decline curves for free gas and gas hydrates. (When a gas hydrate is present the pressure should follow a sawtooth curve as gas is intermittently vented from the PCB. Redrawn after Hunt [1979, p. 161].)

If gas hydrate is present and the gas is released at the same rate at which free gas is formed by gas-hydrate decomposition, there will be no change in pressure until the gas hydrate is completely decomposed, at which time normal pressure decline will occur (Fig. 6). With intermittent release of gas a sawtooth curve results, as shown 
in Figure 6. Release of small amounts of gas causes the pressure to drop. When the valve is closed the pressure will increase toward the theoretical gas-hydrate pressure as decomposition of the gas hydrate takes place. This increase in pressure each time the valve is closed confirms the presence of gas hydrates.

Figures 3,4 , and 5 show the pressure changes that took place during the degassing of PCB-1, PCB-3, and PCB-5. Because we could not measure the volumes of gas released, these figures differ from Figure 6 in that pressure is measured against time rather than against volume of gas produced. All of the pressure curves from the three PCBs showed "sawtooth" characteristics suggesting that gas hydrates were present, but inefficient transfer of gas coming out of solution in sediment confined in the core liner could also have produced similar results. Nevertheless, the fact that pressure returned twice to about $2 \mathrm{MPa}$ after PCB-1 was vented to the atmosphere (Fig. 3) suggests that gas hydrates were present in this sample. Pressure changes on venting PCB-3 did not return to previous values (Fig. 4), suggesting that most of the gas came from solution and little was in the form of decomposing gas hydrates. PCB-5 showed pressure changes (Fig. 5) during the first $2 \mathrm{hr}$. that almost returned to previous values after venting, but the results do not unequivocally signal the presence of gas hydrates.

The results from the PCB experiments provide tentative evidence for the presence of gas hydrates at Site 533 . The amount of gas hydrate indicated is very small, and this conclusion agrees with the visual evidence obtained when the sediment in the PCB cores was examined. Only PCB-1 had frothy, very disrupted sediment that strongly suggested gas hydrates had been present. The sediments in PCB-3, PCB-4, and PCB-5 contained gaps and some disruptions but no obvious evidence of gas hydrates.

\section{ANALYSES OF GASES FROM PCBS}

Preliminary analyses of gases vented from PCB-3, PCB-4, and PCB-5 were obtained on board ship using instrumentation described in the Site 533 report (Sheridan, Gradstein, et al., this volume). The points on the pressure release curves (Figs. 4 and 5) of PCB-3 and PCB-5 where cylinders were filled is indicated by the cylinder number; gases were analyzed aboard ship from those cylinders with underlined identification numbers. The results are shown in Table 2 . More detailed chemical, as well as isotopic, studies were carried out on shore, and this work is described by Brooks et al. (this volume).

The most abundant hydrocarbon gas vented from the PCBs is methane $\left(C_{1}\right)$, which ranged from 76 to $96 \%$ of the gas mixtures recovered from PCB-3 and from 94 to $97 \%$ in gas mixtures from PCB-5. Gas collected in the one cylinder from PCB-4 had only $7 \% \mathrm{C}_{1}$, and this result indicates that gas was lost during the sampling procedure and the cylinder contaminated with air. Ethane $\left(C_{2}\right)$ is the most abundant of the higher molecular-weight hydrocarbon gases. $\mathrm{C}_{2}$ is consistently more abundant in samples from PCB-5 than in samples from PCB-3. Ratios of $C_{1} / C_{2}$ did not vary significantly during degassing. This constant ratio is particularly evident during the degassing of PCB-5. The average $\mathrm{C}_{1} / \mathrm{C}_{2}$ ratios for PCB-3, PCB-4 (one number), and PCB-5 are 6000, 5400, and 4100 , respectively. These ratios compare favorably with the average $C_{1} / C_{2}$ ratios of 9000,3800 , and 4100 , respectively, from gas pockets in sediments from nearby sediment intervals (Sheridan, Gradstein, et al., this volume). These results contrast with observations made on DSDP Leg 42B in the Black Sea (Ross, Neprochrov, et al., 1978b). At Site 380 a PCB retained pressure, and the $\mathrm{C}_{1} / \mathrm{C}_{2}$ ratio of released gas was about 18,000 , whereas gas recovered from unpressurized cores from nearby sediment intervals had $\mathrm{C}_{1} / \mathrm{C}_{2}$ ratios of about 2000 . The difference observed at Site 380 in the measured $C_{1} / C_{2}$ ratios is probably an artifact of the sampling procedure.

Other hydrocarbon gases recovered from PCB-3, PCB-4, and PCB-5 (Table 2) are propane $\left(\mathrm{C}_{3}\right)$, i-butane (i- $\left.\mathrm{C}_{4}\right), n$-butane $\left(n-\mathrm{C}_{4}\right)$, i-pentane (i- $\left.\mathrm{C}_{5}\right)$, and $n$-pentane $\left(n-C_{5}\right)$. The concentrations of these gases generally increase during degassing by factors of about 2 to 4 . This increase in the abundance of these gases during degassing is expected, because these lower-volatility substances would preferentially be retarded during the degassing of the PCB. Why the $\mathrm{C}_{2}$ concentration did not increase and the $C_{1} / C_{2}$ ratios decrease during degassing is not known. Besides the hydrocarbons $\mathrm{C}_{3}$ through $\mathrm{C}_{5}, \mathrm{CO}_{2}$ also tends to increase in abundance during the degassing procedure. For PCB-3, $\mathrm{CO}_{2}$ ranges from 0.4 to $4.7 \%$, and for PCB-5 it ranges from 0.2 to $2.4 \%$.

These preliminary, shipboard analyses of gases recovered from these PCBs indicate that gas composition of sediments can be obtained with a minimum amount of air contamination. Our results do not provide unique insights into the gas composition of gas hydrates, because, as discussed earlier, PCB-3, PCB-4, and PCB-5 apparently did not contain sediments with large amounts of gas hydrates. In fact, evidence for gas hydrates in these sediments was minimal.

\section{CONCLUSIONS}

The successful deployment of the Mod. III PCB at Site 533 means that this tool is no longer an experimental development, but rather an operational achievement that joins other DSDP technological advances. Sediments of the Blake Outer Ridge were recovered at in situ pressures. Studies of the pressure changes taking place during intermittent degassing of these sediments provided tentative but equivocal evidence for gas hydrates at Site 533. The composition of gases released during the degassing procedures was mainly $\mathrm{C}_{1}$ accompanied by $\mathrm{CO}_{2}$ and low amounts of $\mathrm{C}_{2}$ through $\mathrm{C}_{5}$ hydrocarbons. Because the amount of gas hydrates in PCB-3, PCB-4, and PCB-5 was probably small, the gas composition measured does not likely reflect the gas content of gas hydrates but rather the general composition of gases disbursed throughout these sediments.

\section{ACKNOWLEDGMENTS}

We thank T. L. Vallier and M. Storms for their critical reviews of this paper.

\section{REFERENCES}

Benson, W. E., Sheridan, R. E., and Shipboard Scientific Party, 1978. Site 388: lower continental rise hills. In Benson, W. E., Sheridan, 
R. E., et al., Init. Repts. DSDP, 44: Washington (U.S. Govt. Printing Office), 23-67.

Creager, J. S., Scholl, D. W., and Shipboard Scientific Party, 1973. Site 185. In Creager, J. S., Scholl, D. W., et al., Init. Repts. DSDP, 19: Washington (U.S. Govt. Printing Office), 169-216.

Hunt, J. M., 1979. Petroleum Geochemistry and Geology: San Francisco (W. H. Freeman).

Kvenvolden, K. A., and Barnard, L. A., in press. Hydrates of natural gas in continental margins. Proceedings of Hedberg Conference: Tulsa (Am. Assoc. Pet. Geol.).

Kvenvolden, K. A., and McMenamin, M. A., 1980. Hydrates of natural gas: a review of their geologic occurrence. U.S. Geol. Surv. Circ., 825:1-11.

Larson, V. F., Robson, V. B., and Foss, G. N., 1980. Deep ocean coring-recent operational experiences of The Deep Sea Drilling Project. 55th Ann. Fall Tech. Conf. and Exhibition, Soc. Pet. Eng. AIME, SPE 9409:1-9.

Ross, D. A., Neprochrov, Y. P., and Shipboard Scientific Party, 1978a. Site 379. In Ross, D. A., Neprochnov, Y. P. et al., Init. Repts.
DSDP, 42, Pt. 2: Washington (U.S. Govt. Printing Office), 29-118.

1978b. Site 380. In Ross, D. A., Neprochnov, Y. P., et al., Init. Repts. DSDP, 42, Pt. 2: Washington (U.S. Govt. Printing Office), 119-291.

1978c. Site 381. In Ross, D. A., Neprochnov, Y. P., et al., Init. Repts. DSDP, 42: Pt. 2: Washington (U.S. Govt. Printing Office), 293-355.

Ross, D. A., Neprochnov, Y. P., and Supko, P. R., 1978. Introduction and explanatory notes, Leg 42B, Deep Sea Drilling Project. In Ross, D. A., Neprochnov, Y. P., et al., Init. Repts. DSDP, 42, Pt. 2: Washington (U.S. Govt. Printing Office), 3-15.

Thiede, J., Vallier, T. L., and Adelseck, C. G., 1981. Deep Sea Drilling Project Leg 62, North Central Pacific Ocean: introduction cruise narrative, principal results, and explanatory notes. In Thiede, J., Vallier, T. L. et al., Init. Repts. DSDP, 62: Washington (U.S. Govt. Printing Office), 5-31.

Date of Initial Receipt: March 29, 1982 